\title{
Advanced immunological studies on the effect of Spirulina in cultured tilapia
}

Abdalla O.A., Eissa I. A.*, Omnia E. Kilany and Shimaa M.Elbahar**

Department of Clinical Pathology; ${ }^{* D e p a r t m e n t ~ o f ~ F i s h ~ d i s e a s e ~ a n d ~}$

Management, Fac. Vet. Med., Suez Canal University, and ** Fac. Vet. Med., Suez Canal University, Egypt.

\section{English Abstract}

This study was undertaken to evaluate the use of spirulina (Arthrospir platensis) as immunity promoter for Nile tilapia, Oreochromis niloticus (L.).A total of 270 fish (50 $\pm 5 \mathrm{~g})$ were randomly distributed into six groups each at a rate of 15 fish per aquarium and fed on a diet containing $0.0,5.0$ or $10.0 \mathrm{~g}$ spirulina $/ \mathrm{kg}$ diet for 6 weeks. Each subdivided into three equal replicates. After the feeding trial, fish of each treatment were challenged by pathogenic Pseudomonas. fluorescens which was given by intraperitoneal (IP) injection. The blood samples were taken after 4and 6weeks for immunological examinations. The results showed that the highest white blood cells (WBCs) ,neutrophils , monocytes and basophils were obtained at $5.0-10.0 \mathrm{~g}$ spirulina $/ \mathrm{kg}$ diet before and after the infection. There were non significant changes in lymphocytes after 4 weeks, while after infection with Pseudomonas. fluorescens lymphocytes increased in groups supplemented with spirulina. Moreover, spirulina enhanced serum lysozyme activity, bactericidal activity, and antioxidant enzymes (GPx and SOD) of treated groups before and after the infection. Total fish mortality 10days were decreased after IP injection with Pseudomonas. fluorescens with the increase of spirulina level in fish diets. The lowest fish mortality was obtained when fish fed $10.0 \mathrm{~g}$ spirulina/kg. These results indicate that spirulina supplementation is promising for disease prevention in tilapia culture, and the optimum level of spirulina in fish diet is $10.0 \mathrm{~g}$ per $\mathrm{kg}$ diet.

\section{Introduction}

Proper nutrition has long been recognized as a critical factor in promoting normal growth and sustaining fish health. Prepared diet not only provide the essential nutrients that are required for normal physiological functioning, but also may serve as the medium by which fish receive other components that may affect their health (Gatlin, 2002). Oreochromis niloticus is one of the most important species within the tilapia species. Abdel-Tawwab and ElMarakby (2004) noted that Nile tilapia, 0. niloticus is omnivorous and can utilize a wide range of food 
items including blue green algae. Spirulina (Spirulina platensis) is a freshwater blue-green filamentous alga, and it is receiving increasing attention for its bioactive components such as vitamins, protein (60-70\%), minerals, polyunsaturated fatty acids, carotenes and other pigments that have antioxidants activity (Madhava et al, 2000; Lin et al, 2007).

Researchers have reported the therapeutic effects of spirulina as a growth promoter, probiotic, and booster of the immune system in animals including fishes (James et al, 2006). In fish, several immunostimulants such as Chitin (Esteban et al., 2001), Lactoferrin, dimerized lysozyme (Siwicki et al, 1998), CPG oligodeoxy nuclleotides (Tassakka and Sakai, 2003) and nisin have been reported and these substances play a promising role in aquaculture by enhancing the resistance of cultured fish against diseases. Recently, spirulina has been speculated to be associated with modulation of the host immune system (Hironobu et al, 2006). Abdel-Tawwab et al, (2008) reported that the highest red blood cells (RBC), white blood cells (WBC), were obtained when O. niloticus fed on diets containing $5.0-10.0 \mathrm{~g}$ spirulina/kg diet. In the same line James et al, (2009) revealed that the hematological parameters (RBC count and $\mathrm{Hb}$ content) were improved in copper exposed Cirrhinus mirigala fed spirulina supplemented diets as against copper exposed fish fed spirulina free diet. Also, Ragab et al, (2012) said that The RBCs, WBCs and PCV values had the highest values during addition of spirulina to diet of $O$ niloticus at different levels of $S$. platensis, also there was increasing in lymphocytes, monocytes, basophils , eosinophils and neutrophils in groups fed on spirulina. Also, Promya and Chitmanat (2011) reported that by increasing spirulina supplementation fish had higher red and white blood cell counts. Andrews et al, (2011) who reported that the erythrocyte count, haemoglobin concentration and the leucocyte count was significsantly higher in Labeo rohita fingerlings fed on diets containing spirulina supplementation compare to control group. Also, Kaoud et al, (2012) recorded that the addition of dried Spirulina platensis improves the haematological parameters (RBCs, $\mathrm{Hb}$ and $\mathrm{Hct}$ ) as these parameters were of normal values and increased significantly in $O$. niloticus exposed to $\mathrm{Hg}$ with Spirulina platensis. This study was conducted to study the effects of graded levels of Spirulina (A. plantensis) on $\mathrm{RBCs}$ and White blood cells (WBC), some oxidative parameters and non-specific immune responses. Besides resistance of Nile tilapia to Psuedomonas fluroscence infection.

\section{Materials and Methods}


Fish: A total number of $270 O$. niloticus with average body weight of $50 \pm 5 \mathrm{~g}$ were obtained from the Central Laboratory for Aquaculture Research, Abbassa, Abo-Hammad, Sharqia, Egypt. They were transported in sterile plastic bags containing water enriched by oxygen $(2 / 3)$ to the lab of the Dept. of Fish Diseases, faculty of veterinary medicine, Suez Canal University. They kept for two weeks under observation for acclimation in glass aquaria $(100 \times 40 \times 50 \mathrm{~cm})$. Fish were fed on the basal diet for 2 weeks. The water was changed daily.

Aquaria: These aquaria were used for holding the experimental fish throughout the period of the present study, (triplicate each treatment). Each aquarium was supplied with chlorine free tap water (Innes, 1966) .The water temperature was kept at $22 \pm 1{ }^{\circ} \mathrm{C}$. The continuous aeration was maintained in each aquarium using an electric air pumping compressors. Settled fish wastes were cleaned daily by siphoned with three quarters of the aquarium's water, which was replaced by aerated water from the water storage tank.

Diet preparation: A basal diet was formulated to contain $30.6 \%$ crude protein diet. The diet was daily provided at a fixed feeding ratio of $3 \%$ of body weight of fish according to Eurell et al, (1979). The daily amount of food was offered as two equal meals /day on two occasions over the day (9Am and12 PM).

S. platensis used in the present study was obtained from agent chemical laboratories. Redmond, WA, USA.

\section{Pathogen:}

Pseudomonas

fluorescens strain was kindly supplied by Central Laboratory for Aquaculture Research, Abbassa, Abo-Hammad, Sharqia, Egypt. It was used for serum bactericidal activity and challenge test. Lyophilized Micrococcus lysodekticus, which was used for serum lysozomal activity. (Sigma M3770).

\section{Experimental design:}

The pre-acclimatized fish were divided into six groups each group subdivided into 3 subgroups each group distributed into three aquaria. (Replicates, each 15 fish/ aquarium) Group (I) and (IV) were fed on a basal diet (control), Group (II) and (V) were fed with spirulina supplement at $5.0 \mathrm{~g} / \mathrm{kg}$ diet and Group (III) and (VI) fed with fed with spirulina supplement at 10 $\mathrm{g} / \mathrm{kg}$ diet. Groups (VI, V and VI) post feeding trails (at the end of the month) were experimentally infected I/p with Pseudomonas fluorescens, the mortalities were estimated post challenge infections till the end of the experiment.

Blood sampling: At the 4 weeks and after 6 weeks, fish were fasted for 24 hours immediately prior to blood sampling and five fish per aquaria were randomly chosen. The blood was extracted from the caudal 
blood vessels and divided in two sets of eppendorf tubes. One set contained di potassium salt of EDTA, used as anticoagulant, for the counting of red blood cells (RBC) and white blood cell (WBC), which were done following the methods of Brown (1988). The second set was left with no anticoagulant and centrifuged at $5000 \mathrm{rpm}$ for $5 \mathrm{~min}$ at room temperature, the supernatant serum collected and stored at $-20{ }^{\circ} \mathrm{C}$ in screw caped glass vials until used for serum immunological tests.

Lysozyme

activity:Serum lysozyme activity was determined through the turbidimetry described by Engstad et al (1992) by using lyophilized Micrococcus lysodekticus $(\mathrm{OD}=0.3)$ as the substrate in phosphate buffer $(0.1 \mathrm{M}$, PH 6.4)

Serum bactericidal activity: Bacteriocidal activity in fish samples was analyzed according to the Miles- Misra technique Rainger and Rowley (1993).

Measurement of antioxidant enzymes

The activity of Glutathione peroxidase(GPx): Glutathione peroxidase (E.C.1.1.1.1.9), activity was determined by measurement of the reduced glutathione substrate (GSH) remaining after the action of the enzyme using the combined methods of Chiu et al (1976) with
Ellmans reagent in presence of cumene hydroperoxide as a secondary substrate. The unit of enzyme activity is the amount of Gpx which consumes1 $\mu$ mol reduced glutathione/ $\mathrm{min}$ in presence of cumene hydroperoxide.

The activity of superoxide dismutase (SOD): The activity of SOD (E.C.1.1.5.1.1) was determined spectrophotometrically at $480 \mathrm{~nm}$ by the epinephrine method by Misra and Fridovich (1972) and it was expressed in (U/g wet $\mathrm{wt}) / \mathrm{ml}$ of blood serum $(\mathrm{U} / \mathrm{ml}$ blood serum).

Challenge test: After month, post feeding trails fish from each treatment groups (VI, V and VI) (10fish/ aquarium) were challenged with pathogenic $P$. fluorescens. The fish were injected intraperitoneally with $0.2 \mathrm{ml}$ sterile saline containing $\left(1.5 \times 10^{\wedge} / \mathrm{ml}\right)$ pathogenic strain of Pseudomonas flourescens, according to El-Attar and Moustafa (1996).

Statistical analysis: The obtained data were subjected to one-way ANOVA to evaluate the effect of spirulina supplement. Differences between means were tested at the 5\% probability level using Duncan Multiple Range test. All the statistical analyses were done using SPSS program version 10 (SPSS, Richmond, VA, USA) as described by Dytham (1999). 
Table (1): Design of the experiment:

\begin{tabular}{|c|c|c|}
\hline $\begin{array}{c}\text { Treatments } \\
\text { (Groups) }\end{array}$ & Diet & Infection \\
\hline I & Basal diet & Not infected \\
\hline II & Basal diet containing 5g Spirulina $/ \mathrm{kg}$ diet & Not infected \\
\hline III & Basal diet containing 10g Spirulina $/ \mathrm{kg}$ diet & Not infected \\
\hline IV & Basal diet & Infected \\
\hline V & Basal diet containing 5g Spirulina $/ \mathrm{kg}$ diet & Infected \\
\hline VI & Basal diet containing 10g Spirulina/kg diet & Infected \\
\hline
\end{tabular}

\section{Results \\ Hematological and leukogram results:}

In the present study, the results after 4 weeks showed that fish fed on diets containing spirulina exhibited higher RBCs counts compared with the control (Table2). While, the results after ${ }^{7}$ weeks showed that RBCs counts were decreased in all infected groups. While the RBCs counts were stable in infected fish fed on spirulina(Table3). The WBCs counts after 4 weeks had the highest values during addition of spirulina, Also, there was increasing in the neutrophils counts followed by monocytes during the addition of spirulina in groups (II, III). Also after 6weeks WBCs, neutrophils, monocytes and lymphocytes counts were increased in all infected groups, in which the highest count were obtained in $1 \%$ spirulina infected groups (VI)and the lowest count were obtained in the control infected group (IV).

\section{Immunological results:}

Lysozyme activity: the results showed that After 4 weeks serum lysozyme activity showed the highest values at spirulina1\%group (III). (table4). However, after 6 weeks the serum lysozyme activity in non infected groups was increased by the increase of spirulina supplementation in diet. While the challenged groups showed the highest values than non challenged groups, in which the highest values of lysozyme activity at $1 \%$ spirulina infected group (VI) (table5).

Bactericidal activity: after 4 and 6 weeks increased significantly with the increase of spirulina supplementation. Moreover, the bactericidal activity in challenged groups showed highest values than non challenged groups, in which the highest values of bactericidal activity were obtained at $1 \%$ spirulina infected group (VI)(table4 and 5).

Antioxidant enzymes The results showed that After 4 weeks, serum GPx and SOD showed highest values at spirulina $1 \%$ group (III), while the lowest values were obtained at control group (I) (table4). while, After 6weeks the serum GPx and SOD in non 
infected groups were increased by increase of spirulina supplementation in diet, however challenged groups showed highest values than non challenged groups, in which the highest values of serum GPx and SOD at $1 \%$ spirulina infected group(VI) (table5).
The Mortality Rate and the Relative Level of Protection (RLP):

The mortality rate was significantly lower in all $S$. platensis supplemented groups than the control. Also, the results evoked significant protection in all $S$. platensis supplemented groups than the control (table 6).

Table (2): Effect of Spirulina platensis on hematological parameters of O.niloticus fed on practical diets containing different levels of spirulina after 4 weeks:

\begin{tabular}{|c|c|c|c|c|c|c|}
\hline Items & $\begin{array}{l}\text { Control } \\
\text { (I) }\end{array}$ & $\begin{array}{l}\text { Spirulina } \\
0.5 \%(\text { II) }\end{array}$ & $\begin{array}{c}\text { Spirulina } \\
1 \% \text { (III) }\end{array}$ & $\begin{array}{c}\text { Control } \\
\text { infected } \\
\text { (IV) }\end{array}$ & $\begin{array}{l}\text { Spirulina } 0.5 \% \\
\text { infected }(\mathrm{V})\end{array}$ & $\begin{array}{c}\text { Spirulina 1\% } \\
\text { infected } \\
\text { (VI) }\end{array}$ \\
\hline $\operatorname{RBCs} \times 10^{6} / \mu \mathrm{l}$ & $1.06 \pm .06^{b}$ & $1.87 \pm 0.50^{b}$ & $2.3 \pm 0.15^{\mathrm{a}}$ & $1.05 \pm 0.02^{b}$ & $1.9 \pm 0.51^{\mathrm{b}}$ & $2.4 \pm 0.05^{\mathrm{a}}$ \\
\hline WBCs $\times 10^{3} / \mu \mathrm{l}$ & $25.9 \pm 0.7^{\mathrm{c}}$ & $34.8 \pm .24^{b}$ & $63.96 \pm .26^{\mathrm{a}}$ & $26 \pm 0.57^{c}$ & $35 \pm 0.57^{b}$ & $63.6 \pm 0.92^{\mathrm{a}}$ \\
\hline $\begin{array}{c}\text { Neutrophils } x \\
10^{3} / \mu \mathrm{l}\end{array}$ & $8.6 \pm 0.6^{c}$ & $14 \pm 0.57^{b}$ & $32.75 \pm 0.43^{a}$ & $8.8 \pm 0.46^{\mathrm{c}}$ & $13.9 \pm 0.51^{b}$ & $32.6 \pm 0.92^{a}$ \\
\hline $\begin{array}{c}\text { Lymphocytes } x \\
10^{3} / \mu \mathrm{l}\end{array}$ & $11.5 \pm 0.5^{\mathrm{a}}$ & $11.56 \pm 0.31^{\mathrm{a}}$ & $11.62 \pm 0.35^{\mathrm{a}}$ & $11.3 \pm 0.75^{\mathrm{a}}$ & $11.6 \pm 0.92^{a}$ & $11.7 \pm 0.98^{\mathrm{a}}$ \\
\hline $\begin{array}{c}\text { Monocytes } x \\
10^{3} / \mu \mathrm{l}\end{array}$ & $2.7 \pm 0.7^{\mathrm{c}}$ & $5.8 \pm 0.18^{b}$ & $14.3 \pm 0.17^{\mathrm{a}}$ & $2.7 \pm 0.40^{\mathrm{c}}$ & $5.9 \pm 0.51^{b}$ & $14.2 \pm 0.69^{\mathrm{a}}$ \\
\hline $\begin{array}{c}\text { Eosinophils } x \\
10^{3} / \mu \mathrm{l} \\
\end{array}$ & $2.1 \pm 0.1^{a}$ & $2.4 \pm 0.23^{\mathrm{a}}$ & $2.64 \pm 0.36^{a}$ & $2.2 \pm 0.07^{a}$ & $2.5 \pm 0.28^{\mathrm{a}}$ & $2.6 \pm 0.34^{\mathrm{a}}$ \\
\hline $\begin{array}{c}\text { Basophils } \times 10^{3} \\
/ \mu \mathrm{l}\end{array}$ & $1.0 \pm 0.5^{c}$ & $1.0 \pm 0.5^{b}$ & $2.64 \pm 0.36^{\mathrm{a}}$ & $1 \pm 0.57^{c}$ & $1.1 \pm 0.57^{b}$ & $2.5 \pm 0.88^{\mathrm{a}}$ \\
\hline
\end{tabular}

Data in the same raw with different superscript are significantly different $(\mathrm{P}<0.05)$ Table (3): Effect of Spirulina platensis on hematological parameters of O.niloticus fed practical diets containing different levels of spirulina after 6 weeks:

\begin{tabular}{|c|c|c|c|c|c|c|}
\hline Items & $\begin{array}{r}\text { Control } \\
\text { (I) }\end{array}$ & $\begin{array}{l}\text { Spirulina } \\
0.5 \% \text { ( II) }\end{array}$ & $\begin{array}{l}\text { Spirulina } \\
1 \% \text { (III) }\end{array}$ & $\begin{array}{c}\text { Control } \\
\text { infected } \\
\text { (IV) }\end{array}$ & $\begin{array}{c}\text { Spirulina0.5\% } \\
\text { infected(V) }\end{array}$ & $\begin{array}{c}\text { Spirulina } \\
1 \% \\
\text { infected } \\
\text { (VI) }\end{array}$ \\
\hline$\underset{\mu \mathrm{l}}{\operatorname{RBCs} \times 10^{6}}$ & $1.07 \pm 0.04^{\mathrm{cd}}$ & $1.92 \pm 0.04^{\mathrm{ab}}$ & $2.53 \pm 0.92^{\mathrm{a}}$ & $0.9 \pm 0.2^{d}$ & $1.7 \pm 0.40^{\mathrm{bc}}$ & $2.08 \pm 0.80^{\mathrm{ab}}$ \\
\hline$\underset{/ \mu \mathrm{l}}{\mathrm{WBCs} \times 10^{3}}$ & $26.2 \pm 0.40^{f}$ & $35.8 \pm 0.08^{\mathrm{e}}$ & $64.6 \pm 0.20^{c}$ & $26 \pm 0.28^{d}$ & $84.8 \pm 0.28^{d}$ & $120 \pm 0.17^{\mathrm{a}}$ \\
\hline $\begin{array}{c}\text { Neutrophils } \\
\times 10^{3} / \mu \mathrm{l}\end{array}$ & $8.7 \pm 0.40^{e}$ & $14.23 \pm 0.13^{d}$ & $32.69 \pm 0.39^{c}$ & $33.6 \pm 0.34^{c}$ & $40.84 \pm 0.48^{b}$ & $52.4 \pm 023^{\mathrm{a}}$ \\
\hline $\begin{array}{c}\text { Lymphocytes } \\
\times 10^{3} / \mu \mathrm{l} \\
\end{array}$ & $11.5 \pm 0.28^{d}$ & $11.51 \pm 0.29^{d}$ & $11.62 \pm 0.35^{d}$ & $16.9 \pm 0.51^{c}$ & $20.88 \pm 0.50^{b}$ & $30.6 \pm 0.34^{a}$ \\
\hline $\begin{array}{c}\text { Monocytes } x \\
10^{3} / \mu \mathrm{l}\end{array}$ & $2.7 \pm 0.40^{f}$ & $5.86 \pm 0.49^{\mathrm{e}}$ & $14.31 \pm 0.17^{\mathrm{c}}$ & $8.2 \pm 0.11^{\mathrm{d}}$ & $18.24 \pm 0.14^{b}$ & $33.6 \pm 0.35^{b}$ \\
\hline $\begin{array}{c}\text { Eosinophils } x \\
10^{3} / \mu \mathrm{l}\end{array}$ & $2.1 \pm 0.06^{\mathrm{a}}$ & $2.05 \pm 0.02^{a}$ & $2.64 \pm 0.37^{\mathrm{a}}$ & $2.2 \pm 0.11^{a}$ & $2.1 \pm 0.16^{a}$ & $2.2 \pm 0.12^{b}$ \\
\hline $\begin{array}{c}\text { Basophils x } \\
10^{3} / \mu \mathrm{l} \\
\end{array}$ & $1 \pm 0.28^{b}$ & $1.45 \pm 0.03^{b}$ & $2.64 \pm 0.36^{\mathrm{a}}$ & $1.11 \pm 0.05^{b}$ & $1.52 \pm 0.30^{b}$ & $1.2 \pm 0.12^{b}$ \\
\hline
\end{tabular}

Data in the same raw with different superscript are significantly different $(\mathrm{P}<0.05)$ 
Table (4): Effect of Spirulina platensis on immunity and oxidative stress in serum of O.niloticus fed practical diets containing different levels of spirulina after 4 weeks

\begin{tabular}{|c|c|c|c|c|c|c|}
\hline Items & $\begin{array}{c}\text { Control } \\
\text { (I) }\end{array}$ & $\begin{array}{l}\text { Spirulina } \\
0.5 \% \text { (II) }\end{array}$ & $\underset{\text { (III) }}{\text { Spirulina }} 1 \%$ & $\begin{array}{c}\text { Control } \\
\text { infected } \\
\text { (VI) }\end{array}$ & $\begin{array}{c}\text { Spirulina } \\
0.5 \% \\
\text { infected(V) }\end{array}$ & $\begin{array}{c}\text { Spirulina } \\
1 \% \text { infected } \\
\text { (VI) }\end{array}$ \\
\hline $\begin{array}{c}\text { Lyzsozyme } \\
\text { activity }\end{array}$ & $7.95 \pm 0.15^{c}$ & $9.3 \pm 0.285^{b}$ & $11.35 \pm 0.23^{\mathrm{a}}$ & $8.16 \pm 0.20^{c}$ & $9.4 \pm 0 . .80^{b}$ & $11.24 \pm 0.69^{\mathrm{a}}$ \\
\hline $\begin{array}{l}\text { Bactericidal } \\
\text { activity }\end{array}$ & $46.35 \pm 0.85^{c}$ & $61.1 \pm 0.55^{b}$ & $68.00 \pm 0.52^{\mathrm{a}}$ & $46.33 \pm 0.44^{c}$ & $63.4 \pm 1.72^{b}$ & $68.16 \pm 0.4^{\mathrm{a}}$ \\
\hline GPx & $0.12 \pm .05^{\mathrm{c}}$ & $0.14 \pm 0.01^{\text {abc }}$ & $0.18 \pm 0.01^{a}$ & $0.11 \pm 0.01^{\mathrm{c}}$ & $0.13 \pm 0.02^{a b c}$ & $0.17 \pm 0.02^{a b}$ \\
\hline SOD & $0.47 \pm 0.05^{c}$ & $0.7 \pm 0.02^{b}$ & $0.80 \pm 0.02^{a}$ & $0.48 \pm 0.03^{\mathrm{c}}$ & $0.69 \pm 0.05^{b}$ & $0.82 \pm 0.06^{a}$ \\
\hline
\end{tabular}

Data in the same raw with different superscript are significantly different $(\mathrm{P}<0.05)$

Table: (5) Effect of Spirulina platensis on immunity and oxidative stress in serum of O.niloticus fed practical diets containing different levels of spirulina after 6 weeks

\begin{tabular}{|c|c|c|c|c|c|c|}
\hline Items & $\begin{array}{c}\text { Control } \\
\text { (I) }\end{array}$ & $\begin{array}{c}\text { Spirulina } \\
\text { (II) }\end{array}$ & $\underset{\text { (III) }}{\text { Spirulina }} 1 \%$ & $\begin{array}{l}\text { Control } \\
\text { infected } \\
\text { (VI) }\end{array}$ & $\begin{array}{c}\text { Spirulina } \\
0.5 \% \\
\text { infected (V) }\end{array}$ & $\begin{array}{l}\text { Spirulina } \\
1 \% \text { infected } \\
\text { (VI) }\end{array}$ \\
\hline $\begin{array}{c}\text { Lyzsozyme } \\
\text { activity }\end{array}$ & $8.69 \pm 0.29^{f}$ & $10.05 \pm 0.10^{\mathrm{e}}$ & $11.83 \pm 0.20^{d}$ & $14.9 \pm 0.23^{c}$ & $17.73 \pm 0.24^{b}$ & $20.80 \pm 0.34^{\mathrm{a}}$ \\
\hline $\begin{array}{c}\text { Bactericidal } \\
\text { activity }\end{array}$ & $46.86 \pm 0.54^{\mathrm{e}}$ & $62.63 \pm 0.40^{d}$ & $70.66 \pm 0.33^{b}$ & $64.86 \pm 0.38^{\mathrm{c}}$ & $70.8 \pm 0.26^{b}$ & $83.8 \pm 0.45^{a}$ \\
\hline GPx & $0.11 \pm 0.01^{\mathrm{e}}$ & $0.15 \pm 0.01^{d}$ & $0.18 \pm 0.01^{c}$ & $0.19 \pm 0.01^{c}$ & $0.27 \pm 0.01^{b}$ & $0.31 \pm 0.01^{a}$ \\
\hline SOD & $0.48 \pm 0.03^{d}$ & $0.73 \pm 0.02^{c}$ & $0.85 \pm 0.03^{\text {bc }}$ & $0.81 \pm 0.03^{\text {bc }}$ & $0.92 \pm 0.03^{b}$ & $1.09 \pm 0.01^{\mathrm{a}}$ \\
\hline
\end{tabular}

Data in the same raw with different superscript are significantly different $(\mathrm{P}<0.05)$

Table: (6) Mortality and relative level of protection of experimental $O$. nloticus at end of the study of feeding supplemented diet with Spirulina after challenged with Pseudomonas fluorescens

\begin{tabular}{|c|c|c|c|c|c|c|}
\hline Items & $\begin{array}{l}\text { Control } \\
\text { (I) }\end{array}$ & $\begin{array}{c}\text { Spirulina } \\
\mathbf{0 . 5 \%} \\
\text { (II) }\end{array}$ & $\begin{array}{c}\text { Spirulina } \\
1 \% \\
\text { (III) }\end{array}$ & $\begin{array}{c}\text { Control } \\
\text { infected } \\
\text { (IV) }\end{array}$ & $\begin{array}{c}\text { Spirulina } \\
0.5 \% \\
\text { infected(V) }\end{array}$ & $\begin{array}{l}\text { Spirulina } \\
1 \% \text { infected } \\
\text { (VI) }\end{array}$ \\
\hline $\begin{array}{c}\text { Number of } \\
\text { dead fish }\end{array}$ & \multirow[t]{2}{*}{0.00} & \multirow[t]{2}{*}{0.00} & \multirow[t]{2}{*}{0.00} & 15 & 8 & 4 \\
\hline Mortality \% & & & & $75 \%$ & $40 \%$ & $20 \%$ \\
\hline R LP\% & 0.00 & 0.00 & 0.00 & 0.00 & $25.66 \%$ & 73.34\% \\
\hline
\end{tabular}

\section{Discussion}

The blood parameters as leucocytic counts and differential leucocytic counts have diagnostic importance and usually readily respond to identical factors such as physical, chemical and biological stressors (Hicky, 1976 and Soliman, 1996).
Erythrocytes are a major and reliable indicator of various sources of stress (Rehulka 1989). In the present study, fish fed on diets containing spirulina exhibited higher RBCs counts. These results in agreement with Abdel-Tawwab et al (2008) who reported that the highest RBCs counts were obtained 
when Oreochromis niloticus fed on diets containing $5.0-10.0 \mathrm{~g}$ spirulina/kg diet. Also, Ragab (2009), Andrews et al (2011) and Promya and Chitmanat (2011) who reported that the erythrocyte count was significantly higher in fish fed on diets containing spirulina supplementation compare to control group. Our results may be due to spirulina has $14 \%$ phycocyanin and it stimulates the erythropoietin hormone production for hematopoesis (Henrikson, 1994). And/or the increase of RBCs counts is a response to tolerate stress or on the other hand is a measure to maintain general health (Sivagurunathan et al, 2012). The results after 7 weeks showed that RBCs counts were decreased in all infected groups, the lowest count were obtained in the control infected (IV). The decrease in RBCs counts may be attributed to observe hemorrhages and red blood cell lysis (Wafaa, 2007) which results in severe anemia (James et al, 1992) And/or Erythrocytes are a major and reliable indicator of various sources of stress (Rehulka, 2000

The WBCs counts after 4 weeks had the highest values during addition of spirulina, Also, there was increasing in the neutrophils counts followed by monocytes during the addition of spirulina. Also, after 6weeks WBCs, neutrophils, monocytes and lymphocytes counts were increased in all infected groups. The results are in agreement to data obtained by (Gupta et al, 1979 and Edvington et al, 1994) who cleared that fish not received any immunostimulants or live under stress conditions showed decreased leucocytes count and increase susceptibility to infection. In the same line with Andrews et al, (2011) who stated that the leucocytic count was significantly higher in Labeo rohita fingerlings fed on diets containing spirulina supplementation compare to control group.

The high level of WBCs, monocytes, and lymphocytes in infected groups in the agreement with Wafaa (2007) who cleared that the infected fish with Pseudomonas fluorescens showed that significant increase in total leucocytic count as well as increased lymphocytic count. Moreover Abdel-Tawwab et al (2010) observed an increase in WBC and Lymphocyte counts in Nile Tilapia fed with feed incorporated with Green Tea and infected with Aeromonas hydrophila. Similar increase in WBC, neutrophils, lymphocytes and monocytes were observed in Cirrhinus mrigala fed with feed supplemented with Ginger and Turmeric and infected with P.aeruginosa by Sivagurunathan et al (2012). The obtained results may be due to there is evidence that cphycocyanin and polysaccharides of spirulina enhance white blood cell production (Qureshi and Ali, 1996). Studies have shown that phycocyanin affects the stem cells 
which found in the bone marrow. Stem cells are the "grandmother" of both white blood cells that make up the cellular immune system and the red blood cells that oxygenate the body (Kithja, 2005). Also, Hayashi et al (2006) cleared that the spirulina extract, hot- water extract, Phycocyanin, and cell- wall component extract, enhanced proliferation of bone marrow cells in mice.The high level of WBCs, monocytes, and lymphocytes in infected groups may be due to leucocytes are centrally involved in phagocytic and as immune responses to parasitic, bacterial, viral and similar challenges (Houstan, 1990). Thus increase in the TLC, neutrophils, monocytes and lymphocytes in spirulina incorporated diet fed fishes can be attributed to the non-specific immune response and increase in lymphocytes may be a specific pathogen induced Immune response.

Lysozyme is an enzyme found in a wide range of vertebrates including fish and is one of the defensive factors against invasion by microorganisms as it act as nonspecific component of innate immunity (Hansen, 1974).

In the present study, the results showed that after 4 weeks serum lysozyme activity was significant in all fish groups given basal diet supplemented with $S$. platensis. Results were in accordance with (Khalil et al, 2007; Ragab et al; 2012 and Promya and Chitmanat,
2011) who reported that spirulina enhanced responses of lysozyme activity of fish. The increase in the immunity stimulating capacity (measure by a lysozyme activity assay) could be due to the presence of C-phycocyanin in the spirulina alga, which can help build the immunity capacity (Vonshak, 1997). After 6weeks the serum lysozyme activity in non infected groups were increased by increase of spirulina supplementation in diet. While the challenged groups showed highest values than non challenged groups. Results were in accordance with (Manal et al, 2011) that cleared that lysozyme activity in serum samples of $P$. florescence challenged groups of Nile tilapia was elevated. The elevation of lysozyme in infected groups may be due to high lysozyme activity may be desirable in cultured fish because it may aid against infection when fish are kept at high densities and consequently are exposed to high bacterial loads (Grinde et al, 1988). And/or in fish , lysozyme is an enzyme with antibiotic properties that is released by leucocytes, has a broader spectrum activity than mammalian lysozyme

(Demers

and

Bayne, 1997) .

In this study bactericidal activity after 4 and 6 weeks increased significantly with the increase of spirulina supplementation. Moreover, the bactericidal activity in challenged groups showed highest values than non challenged 
groups, in which the highest values of bactericidal activity at $1 \%$ spirulina group (VI). This result matches with (Khalil et al, 2007, Abdel-Tawwab et al,2008 and Ragab et al, 2012) who reported that spirulina enhanced responses of bactericidal activity of Oreochromis niloticus. These results may be attributed to the increase in phagocytosis in blood, which have an important role for prevention of infectious disease (Mohan et al, 2006).

In the present study, the results showed that After 4 weeks serum GPx and SOD showed highest values at spirulina 1\%group (III), while the lowest values were obtained at control group (I) This result agreed with (Lin et al

, 2010 and Tayag et al, 2010) who stated that White shrimp $L$. vannamei that had received $S$. platenis had enhanced innate immunity by significantly increased SOD activity, a GPx activity. These results may be due to antioxidant property of Spirulina, earlier studies reported that Spirulina possess significant antioxidant properties as it is rich in carotenoids, flavonoidswhich scavenge free radicals (Bhat and Madyatha, 2000). Selenium present in spirulina induced selenium containing enzyme Glutathione peroxidase $(\mathrm{GPx})$, an enzyme catalyzes the reduction of $\mathrm{H}_{2} \mathrm{O}_{2}$ and hydroperoxides to non-toxic products (Henrikson, 1989).
After 6weeks the serum GPx and SOD in non infected groups were increased by increase of spirulina supplementation in diet, however challenged groups showed highest values than non challenged groups, in which the highest values of serum GPx and SOD were obtained at $1 \%$ spirulina group(VI). These results agreed with (Manal et al, 2011) who cleared that Nile tilapia post bacterial challenge showed that the antioxidant enzyme levels in sera of Pseudomonas florescence challenged group were elevated than control. These results may be due to that pathogenic bacteria could trigger an oxidative stress through-which a group of multifunctional antioxidant enzymes are involved in the detoxification and effective removal of both excessive reactive intermediates and oxygen radicals (Olsvik et al, 2006). These intermediates are responsible for oxidation of biological membranes leading to altered physiological condition, metabolic dysfunction and could ultimately predispose to death (Olsvik et al, 2006).

The challenge infection revealed a significantly lower mortality percentage in the group received 10 $\mathrm{g} / \mathrm{kg} \mathrm{S}$. platensis in diet (group VI) and significantly high relative level of protection (RLP) after challenge infection using $P$. fluorescens. These results may be due to spirulina contains phytopigments such as phycobilins, phycocyanin and allophycocyanin, and 
xanthophylls, which seem to be related to its antioxidant activity (Miranda et al, 1998 and Bhat and Madyastha, 2000).

\section{References}

Abdel-Tawwab, M. and ElMarakby, H. I. (2004): Lengthweight relationship, natural food and feeding selectivity of Nile tilapia; Oreochromis niloticus (L.) in fertilized earthen ponds. In: R. Bolivar, G. Mair and K. Fitzsimmons (eds.), The 6th International Symposium of Tilapia in Aquaculture ISTA(6),14-16, Manila, Philippines,pp 500-509.

Abdel-Tawwab, M.; Ahmad, M. H.; Abdel-Hadi, Y. M. and Seden, M. E. A. (2008): Use of spirulina (Arthrospira platensis) as agrowth and immunity promoter for Nile tilapia, Oreochromis niloticus (L) fry challenged with pathogenic Aeromonas hydrophila. International symposium on tilapia in aquaculture, 1015-103.

Abdel-Tawwab, M.; Ahmad, M. H.; Medhat, E.; Saleh, F.M. (2010): Use of Green Tea, Camellia sinensis $L$, in Practical Diet for growth and production of Nile Tilapia, Oreochromis niloticus (L) against Aeromonas hydrophila Infection. J. of the World Aquaculture Society. (41), 203-213. Andrews, S. R.; Sahu, N. B.; Pal, A. B.; Mukherjee, S. C. and Kumar, S. (2011) : Yeast extract, brewer's yeast and spirulina in diets for Labeo rohita fingerlings affect haemato-immunological responses and survival following Aeromonas hydrophila challenge. Research in Veterinary Science, (91), 103-10.

Bhat, V. B. and Madyastha, K. M. (2000): C-phycocyanin: A potent peroxyl radical scavenger in vivo and in vitro. Bioch. Biophy. Res. Comm., (275), 20-25.

Brown, B. A. (1988): Routine hematology procedures. Pages 7122 in B. A Brown, editor. Hematology, principles and procedures. Leo and Fabiger, Philadelphia, Pennsylvania, USA.

Chiu, D. I. Y.; Stults, P. H. and

Tappal, A. L.; (1976): Purification and preparation of rat lung soluble glutathione peroxidase. Biochem. Biophy. Acta,( 445), 558-566.

Demers, N. E. and Bayne, C. J. (1997): the immediate effects of stress on hormones and plasma lysozyme in rainbow trout. Dev. Comp. Immunol. (21), 363-373.

Dytham, C. (1999): Choosing and Using Statistics: A Biologist's Guide. Blackwell Science Ltd., London, UK.

Edvington, T. S.; Harvey, R. B. and Kubena (1994): Effect of aflatoxin in growing lambs fed ruminally degradable or escape protein sources.J.Anim.sci.72 (5), 74-81.

El-Attar $M$ and Moustafa A. (1996): Experimentally infected Tilapia fish (I/P) with $0.5 \mathrm{ml}$ broth cultured $(3 \times 107$ cell $/ \mathrm{ml})$ of $P$. fluorescens. Assiut. Vet. Med. 35: 155-162.

Engstad, R. E.; Robertsen, B. and Frivold, E. (1992): Yeast glucan 
induces increasin lysozyme and complement-mediated haemolytic activity in Atlantic salmon blood. Fish and Shellfish immunology, (2):287-297

Esteban, M.; Cuesta, A. Ortuno, J. Meseguer, $D$. and Immuno, $J$. (2001): modulatory effects of dietary intake of Chitin on gilthead seabream (Sparusaurata) innate immune system. "Fish shell fish immunol; (11): 303-315.

Eurell, T.; Lewis, S. and

Grumbles, L. (1979): Comparison of selected diagnostic tests for detection of motile Aeromonas septicaemia in fish. Am. J. Vol. Res. 1979; 39 (8): 1384 - 1386.

Gatlin, D. M. III. (2002): In:

Halver, J. E., Hardy, R. W. (Eds).

Fish Nutrition. Academic Press, San Diego, CA, USA, pp 671 - 702. Grinde, B.; Lie, O.; Poppe, T. and Salte, R. (1988): Species and individual variation in lysozome activity in fish of interest in aquaculture. Aquaculture (68), 299304.

Gupta, M.; Sasmal, D. and Bandyopadhay, S. (1979): Effect of ochratoxin A on pentylene tetrazol induced convulsion in mice.IRCS Med.Sci (7), 466.

Hansen, N. E. (1974): Lysozyme assay. Series Haematologica, 7, 1421.

Hayashi, O.; Ono, S.; Ishii, K.; Shi, Y.; Hirahashi, T. and Katoh, T. (2006): "Enhancement of proliferation and differentiation in bone marrow hematopoietic cells by Spirulina (Arthrospira) platensis in mice", Journal of Applied Phycology, (18), 47-56.

Henrikson, R. (1989): Earth food Spirulina. Cited from Recolina Ltd. Renore Enterprises Inc, Launa Beach, California, pp 27-65.

Henrikson, R. (1994): Microalga Spirulina Super Alimento del Futuro Ronore Enterprises. 2nd ed. Urano, Barcelona, Spain. 36 pp.

Hickey, C. R. (1976): Fish hematology its uses and significance. N.Y. Fish Game J. (23), 175-179.

Hironobu, W.; Kazuki, O.; Asmi, C.; Tassakka, T. and Masahiro S. (2006): Immunostimulant effects of dietary Spirulina platensis on carp, Cyprinus carpio. Aquaculture; 258: $157-163$.

Houstan, A. H. (1990): Blood and Circulation. In: Methods for fish Biology, Schreck. CB and P.B Moyle (Eds).American Fisheries Society, USA., ISBN:0-913235-98 $\mathrm{X}: 273-334$.

Innes, W. T. (1966): Exophic Aquarium fishes. $4^{\text {th }}$ ed.Aquc. Inc. Jersy, USA.530-533.

James, R.; Sampath, K.; Jancy Pattu, V. and Devakiamma, $G$. (1992): Utilization of Eichhorina crassipes for the reduction mercury toxicity on food transformation in Heteropneustes fossilis. J. Aqua. Trop., (7), 189- 196.

James R, Sampath K, Thangarathinam $R \quad$ and Vasudhevan I. (2006): Effect of dietary spirulina level on growth, fertility, coloration and leukocyte"count in red swordtail, 
Xiphophorus helleri. Isr. J. Aquacult Bamidgeh, 58:97-104. James, R.; Sampath, K.; Vellaismy, P. and Manikandan, M. M. (2009): Effect of dietary spirulina on reduction of copper toxicity and improvent of growth, blood parameters and phosphates activities in carp,Cirrhinus mrigala. Indian Journal of Experimental Biology (47), 754-759.

Kaoud, H. A.; Mahran, K. H. A.; Rezk, A. and Khalf, M. A. (2012): Bioremediation the toxic effect of mercury on liver histopathology, some hematological parameters and enzymatic activity in Nile tilapia, Oreochromis niloticus. Researcher; 4(1), 60-70.

Khalil, R. H.; Saad, T. T. and Mahfouz, $\quad$ N. B. (2007): Immunostimulant effects of dietary Spirulina platensis. on tilapia (Oreochromis niloticus) . The Eighth Conference and Exhibition on Food Industries between Production Quality and Competitiveness.

Kithja, R. (2005): Growth of Pangasius bocourti Sauvage fed with different level of Spirulina sp in pellet feed. Special Science Problem, Faculty of Fisheries Technology and Aquatic Resources,Macjo University,Thailand.

Lin, W.; Pan, B.; Sheng, J.; Xu, $J$. and $\mathrm{Hu}, Q$. (2007): Antioxidant activity of Spirulina platensis extracts by supercritical carbon dioxide extraction. Food Chem., (105), 36-41.
Lin, Y. C.; Tayag, C. M.; Huang, C. L.; Tsui, W. C. and Chen, J. C. (2010): White shrimp Litopenaeus vannamei that had received the hotwater extract of Spirulina platensis showed earlier recovery in immunity and up-regulation of gene expressions after $\mathrm{pH}$ stress. Fish \& Shellfish Immunology (29), 1092e1098.

Madhava, C.; Bhat, V. B.; Kiranmai, G.; Reddy, M. N.; Reddanna, $P$. and Madyastha, $K$. M. (2000): Selective inhibition of cyclooxygenase- 2 by $\mathrm{C}$ phycocyanin, a biliprotein from Spirulina platensis. Bioch. Biophy. Res. Comm., (277), 599-603.

Manal, M. Z.; Eissa, A. E. and Sherein, S. (2011): Assessment of the Immune Status in Nile Tilapia (Oreochromis niloticus)

Experimentally Challenged with Toxogenic / Septicemic Bacteria During Treatment Trial with Florfenicol and Enrofloxacin. World Journal of Fish and Marine Sciences 3 (1): 21-36.

Miranda, M. S.; Cintra, R. G.; Barros, S. B. and Mancini Filhlo, J. (1998): Antioxidant activity of the microalga Spirulina maxima, Brazilian Journal Medical and Biological Research,(31),10751079.

Misra, H. P. and Fridovich, C. (1972): The role of super oxide anion in the autoxidation of epinephrine and sample assay for superoxide dismutase. J. BiolChem., (247), 3170-3175. 
Mohan, I. K.; Khan, M.; Shobha, J. C.; Naidu, M. U.C.; Prayag, A. and Kuppusamy, P. (2006): Protection against cisplatin-induced nephrotoxicity by Spirulina in rats. Cancer Chem. Pharm., 58(6): 802808.

Olsvik, P. A.; Kristensen, T.; Waagbo, R.; Tollefsen, K. E.; Rosseland, B. O. and Toften, $H$. ( 2006): Effects of hypo- and hyperoxia on transcription levels of five stress genes and the glutathione system in liver of Atlantic cod Gadus morhua. J Experiment Biol., (209), 2893-2901.

Promya, J. and Chitmanat, $C$. (2011): The effects of Spirulina platensis and Cladophora algae on the growth performance, meat quality and immunity stimulating capacity of the African sharptooth catfish (Clarias gariepinus). Int. J. Agric. Biol., (13), 77-82.

Ragap, H. M. (2009): Some studies on Spirulina on some cultured freshwater fish in Egypt. MVSc. Of Vet.(Dept. Fish disease and management) Med. Alex.Univ.

Ragap, H. M.; Khalil, R. H. and Mutawie, H. H. (2012): Immunostimulant effects of dietary Spirulina platensis on tilapia Oreochromis "niloticus. Journal of Applied Pharmaceutical Science 02 (02), 26-31.

Rainger, G. E. and Rowley, A. F. (1993): Antibacterial activity in th e serum and mucus of rainbow trout Oncorhynchus mykiss, following immunization with Aeromonas salmonicidia. Fish and shellfish immunology (3), 475-482.

Rehulka, J. (1989): Determining the optimum doses of Kurasan (ethoxyquinolin) and butylhydroxyto luol (BHT) in dry pellets: effect of(ethoxyquinolin) and butylhydroxytoluol (BHT) in dry pellets: effect of Aquaculture and Fisheries Management.( 20), 295-310.

Rehulka, J. (2000): Influence of astaxanthin on growth rate, condition and some blood indices of rainbow trout Oreochromis mykiss. Aquaculture.; (190), 27-47.

Sivagurunathan, A.; Innocent, $X$. B. and lakshmi, S. M. (2012): Immunomodulatory Effect of Dietary Nelumbo Nucifera (Lotus) in Growth and Haematology of Cirrhinus Mrigala Challenged With Pseudomonas Cirrhinus Mrigala Challenged With Pseudomonas. Journal of Applied Pharmaceutical Science 02 (07), 191-195.

Siwicki, A.; Klein, P.; Mornad, M.; Wiczka, W. and Studnicka, M. (1998): Immunostimulatory effects of dimerized lysozyme (KLP - 206) on the non specific defense mechanisms and protection against furunulosis in salmoniels. Vet. Immunol. Immunopathol. (61)369 378.

Soliman, M. K. (1996): Principles of fish diseases. Effect of stress on immune system of fish. Fac. Vet. Med., J. Alex. Univ., pp. 12-23. Tassakka, A. and Sakai, M. (2003): The in vitro effect of $\mathrm{CpG}$ oligodeoxynucleotides on the innate 
immune response of common carp, Cyprinus carpio L. Aquaculture (220), 27-36.

Tayag, C. M.; Lin, Y.; Li, C.; Liou, C. H. and Chen, J. C.(2010): Administration of the hot-water extract of Spirulina platensis enhanced the immune response of white shrimp Litopenaeus vannamei and its resistance against Vibrio alginolyticus. Fish \& Shellfish Immunology (28), 764e773.
Vonshak, A. (1997): Spirulina platensis (Arthospira): Physiology, Cell Biology and Biotechnology (p. 540). London: Taylor and Francis.

Wafaa, Z. A. (2007): Clinicopathological studies on the effect of pseudomonas infection in fresh water fish. Ph D. Thesis Fac. of Vet. Med.(Clinical Pathology) Suez canal.Univ.

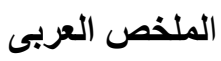

\section{دراسات مناعية متقدمة على تاثير السبيرولينا فى سمك البلطى النيلى

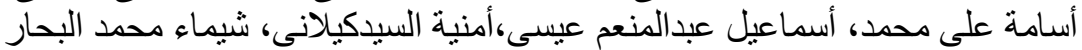

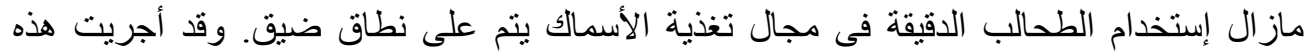
الدراسة بهدف دراسة التاثيرات الناتجة عن إضافة طحلب السبيراتيرولينا (السبيرولينا بلاتنسيس)

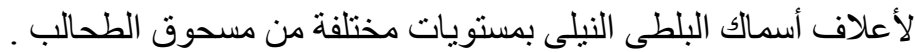

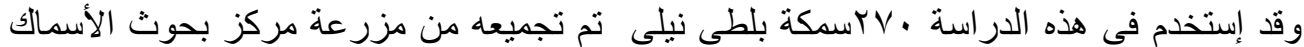

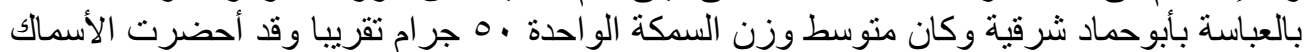

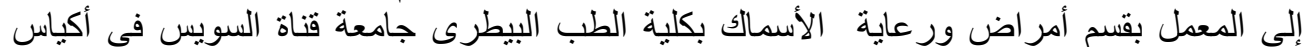

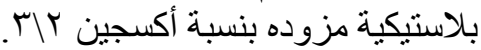

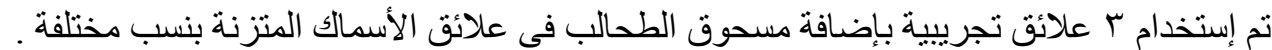

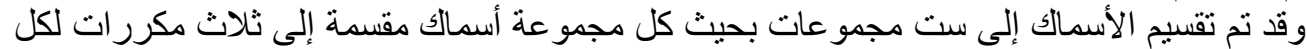

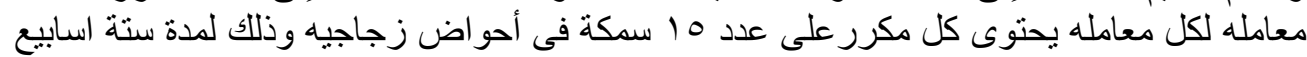
وتركت هذه الأسماك للأقلمة لمدة أسبو عين قبل علئ بداية التجربة.

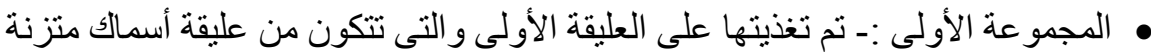

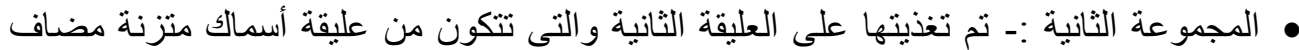
إليها نسبة 0, • \% من مسحوق نفس الطحلب. • المجموعة الثالثة :- نم تغذيتها على العليقة الثالثة و التنى تتكون من عليقة أسماك متزنة مضاف إليها نسبة اله \% من مسحوق نفس الطحلب.

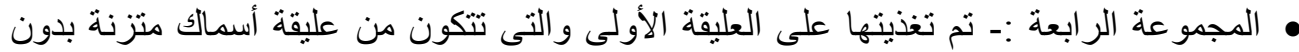

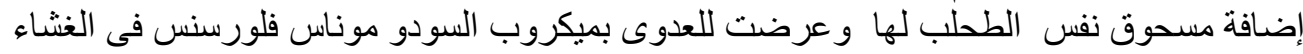
البرينونى بجر عة r , • مل فى نهاية التجربة.

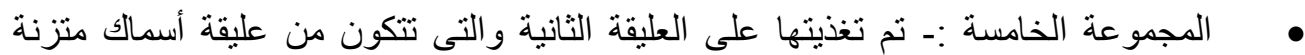
مضاف إليها نسبة ه, •\% من مسحوق نفس الطحلب وعرضت للعدوى لبنفس الميكروب فى نهاية التجربة. 
البجموعة السادسة :- تم تغذيتها على العليقة الثالثة و التى تتكون من عليقة أسماك مثزنة مضاف إليها نسبة (\% من مسحوق نفس الطحلب و عرضت للعدة العدوى بنفس الميكروب فى نهاية التجربة. وأسفرت هذه الدراسة عن النتائج التالية الطيا

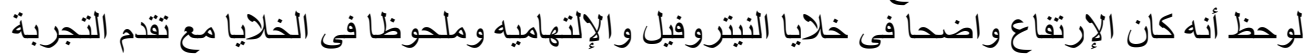

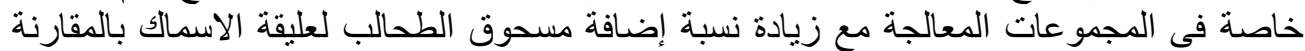

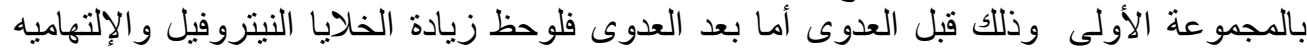

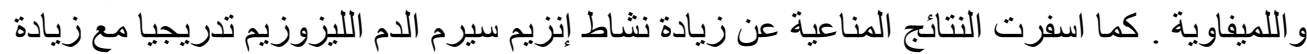

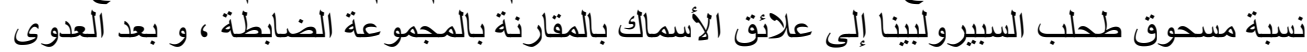

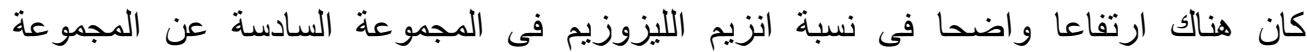

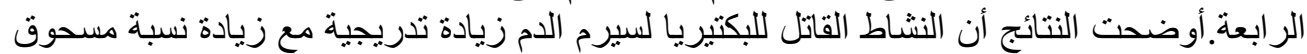

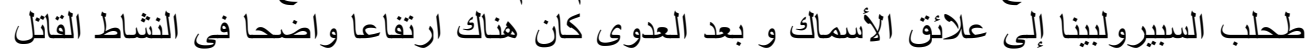

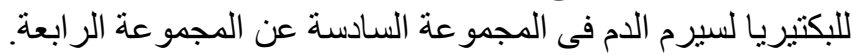

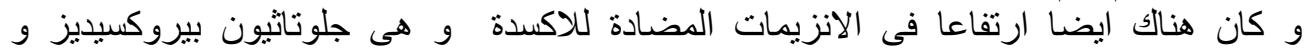

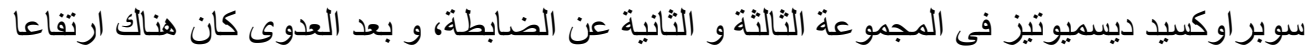

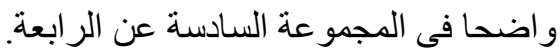

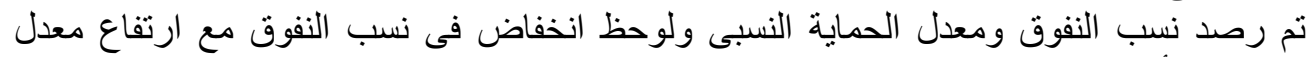
الحماية بالأسماك المغذاة على العليقة المضاف إليها السبيرولينا مقارنة بالمجمو عة الضابطة. 